\title{
Prevalence of caries and DMF-T index with D1-D2 scale on students
}

\author{
Setunggal Agung Nugroho Harahap*, Sri Susilawati*, Dede Sutardjo* \\ *Department of Dental Public Health, Faculty of Dentistry Universitas Padjadjaran, Indonesia
}

ABSTRACT

Introduction: Many factors associated with poor health habits are initiated during adolescence. This is because as a teenager they have the feeling that they are unique and invulnerable that makes them think that the disease or disorder will not enter into their lives. Based on this, teenagers can have a bad habit for their oral health, thus increasing the level of caries in their mouths. The purpose of this study was to get data on the caries experience (DMF-T index) with D1-D2 scale on students. Method: This type of research is descriptive. The technique used in this sampling is simple random sampling, the sample is 266 students consisting of 109 men and 157 women. Prevalence rate of caries adjusted with 2004 Household Health Survey and DMFT category based on World Health Organization. Result: The results showed that the prevalence of caries in college students of Al-Ihsan Islamic boarding school is 90.6\%. DMF-T index in college students of Al-Ihsan Islamic boarding school is 4.18. D1 scale that was found was 280 cases. D2 is the scale found 335 cases. and dental caries were found at 949 cases. Conclusion: Prevalence of caries and DMF-T index with D1-D2 scale on students are prevalence of dental caries is higher than prevalence in 2004 Household Health Survey. DMF-T index is moderate, while the D1 scale found 280 cases and the D2 scale found 335 cases.

Keywords: caries, DMF-T index, and the scale of D1-D2

\section{INTRODUCTION}

According to WHO, healthy itself can be interpreted that a state that is perfect both physically, mentally and socially and its not only free from disease or weakness. ${ }^{1}$ Whereas according to Health Law No. 36 article 1 of 2009, health is a healthy condition, physically, mentally, spiritually and socially that allows everyone to live productively socially and economically. ${ }^{2}$ Based on the explanation above to get a condition called healthy, an individual must be physically, mentally, and socially healthy. ${ }^{2}$

According to WHO, health itself can be interpreted that a state that is perfect both physically, mentally and socially and not only free from illness or weakness. ${ }^{1}$ Whereas according to Health Law No. 36 article 1 of 2009, health is a healthy condition, physically, mentally, spiritually and socially that allows everyone to live productively socially and economically. ${ }^{2}$ Based on the explanation above to get a condition

Corresponding author: Sri Susilawati, Department of Dental Public Health, Faculty of Dentistry Universitas Padjadjaran, Indonesia. Jalan Sekeloa Selatan I, Bandung, West Java, Indonesia, 40132; Phone: +6222-2504985/2532805 
called healthy, an individual must be physically, mentally, and socially healthy. ${ }^{2}$

According to the 1945 Constitution article $28 \mathrm{H}$ paragraph 1 which reads "Every person has the right to live in physical and spiritual prosperity, to live, and to have a good and healthy environment and to have health services", and article 34 paragraph 3 which reads "The State is responsible for providing service facilities proper health and public service facilities ", the state is obliged to be able to provide health services to all its citizens. According to health law No 36 article 9 , the government is obliged to organize health services to improve the dental health status of the population. Therefore, based on the results survey health , the prevalence of dental caries in Indonesia is still high, amounting to $90.05 \%$. The high prevalence of caries is one of the evidences of the poor condition of the teeth and mouth of Indonesian people. ${ }^{2,3}$

Riskesdas data in 2007 also shows that the DMF-T index nationally is $4.85 .{ }^{4}$ This means that the average tooth decay in the Indonesian population is 5 teeth per person. The largest component of the DMF-T index value is tooth extracted / MT of 3.86, it can be said that the average Indonesian population has 4 teeth that have been revoked or an indication of extraction. The DMF-T index for the population of West Java in general is 6,88 . This means that the average tooth decay in the population of West Java is 7 teeth per person. The biggest component is tooth extraction / MT of 3.75 , which means that the average population of West Java has 4 teeth that have been revoked or an indication of extraction. The Riskesdas data provides information about the average level of tooth decay in the population of West Java, but does not show how far the tooth decay is. Therefore to determine the extent of tooth decay can be investigated on a D1-D2 scale. ${ }^{4}$

Al-Ihsan Islamic boarding school is a boarding school located in Cibiru. This boarding school was first established in 1995 with only 15 students. In 2000 this boarding school first received female students. At present the number of santri in the boarding school is 700 people. $98 \%$ of the students are students, most of whom are UIN students. At present the Al-Ihsan boarding school has 4 dormitories, with 2 male and 2 female dormitories. The age of the majority of students in the pesantren ranges from 18 years to 22 years. Adolescence begins around the age of 10 to 13 years and defecates between the ages of 18 and 22 years. 4 This means that most of the students in the Al-Ihsan boarding school are in their late teens. Many factors associated with bad habits for health begin in adolescence. This is because as a teenager they have a feeling that they are unique and invulnerable which makes them think that illness or disorder will not enter their lives . 4 Based on this, adolescents can have bad habits on the health of their oral cavity, thereby increasing the level of caries in their mouth. This is what underlies the authors to conduct research on the prevalence of caries, DMF-T index and D1-D2 scale in students in Al-Ihsan boarding school students. The purpose of this study was to obtain data on caries experience and improve dental and oral health in Al-Ihsan boarding school students .

\section{METHODS}

This type of research is a descriptive study with survey techniques, which is a way of descriptive research conducted on a number of objects in a certain period of time and aims to make an assessment of the conditions and implementation of a program in the present, then the results are used to compile plans for improving the program. The population in this study were students of Al-Ihsan Islamic boarding school students. The population criteria used were: Students of Al-Ihsan Islamic boarding school students were male and female, willing to fill informed consent and become the narrators in this study, and were cooperative .

The sampling technique used in this study is to use simple random sampling. Taking the number of samples using the formula:

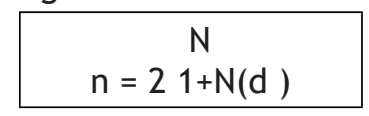

$\mathrm{N}=$ The size of the population to be studied, $\mathrm{n}=$ The size of the sample, $\mathrm{d}=$ Deviation from the population or the desired degree of accuracy.

The level of trust or accuracy in the formula is $5 \%$, so from the total population of students in Al-Ihsan Islamic boarding school, a sample of 255 students was obtained. 


\section{RESULTS}

The sample consisted of 266 respondents registered as students in Al-Ihsan Islamic boarding school. Based on a total of 266 respondents, 109 were male and 157 were female.

DT is the average number of cavities per person , MT $r$ the average number of teeth extracted / indication of extraction, FT $r$ average number of teeth cursed, DMF-T $r$ or the average amount of tooth damage per person (both still in the form of decay, revoked, or cursed ). ${ }^{3}$

Table 2 shows the prevalence of caries in the boarding school students Allhsan by $90,6 \%$. This means that $90,6 \%$ boarding school students of Al-Ihsan have experienced dental caries. Household Health Survey in 2004 showed the prevalence of caries by $90,05 \%$ in the population of Indonesia. This shows that the prevalence rate of caries in students living in Al- Ihsan Islamic boarding school is greater than the results of the 2004 Household Health Survey.

Table 1. Distribution of Respondents by Gender

\begin{tabular}{ccc}
\hline Gender & frequency & $\%$ \\
\hline Male & 109 & 40.98 \\
Girl & 157 & 59.02 \\
\hline Jumlah & 266 & 100 \\
\hline
\end{tabular}

Table 2. Prevalence of Caries Santri Al-Ihsan Islamic Boarding School Number of Santri Caries Samples Prevalence of Caries

\begin{tabular}{ccc}
\hline Jumlah Santri & Sample caries & Prevalence caries \\
\hline 266 & 241 & $90.6 \%$ \\
\hline
\end{tabular}

Table 3. Components D, M, and F in Al-Ihsan boarding school students

\begin{tabular}{cc}
\hline DMF & Amount \\
\hline D & 949 \\
$M$ & 148 \\
F & 17 \\
\hline Jumlah & 1114 \\
\hline
\end{tabular}

Table 4. Components of DT, MT, and FT in Al Ihsan Islamic Boarding School

\begin{tabular}{ccc}
\hline D-T & M-T & F-T \\
\hline 3.56 & 0.55 & 0.06 \\
\hline
\end{tabular}

Table 3 and table 4 present the components of the index $D, M$, and $F$ in students in Al-Ihsan Islamic boarding school students. The DMF-T index as an indicator of dental health is a sum of the DT, MT, and FT index which shows how much tooth decay a person has experienced either in the form of Decay (carious or cavities), Missing (teeth extracted due to caries), and Filling (teeth patched or clogged due to caries 3 (Riskesdas, 2007).

The results of the research shown in table 4 show that the average value of DT in Al-Ihsan Islamic boarding school students is 3.56 which means that there are 3 to 4 teeth that have caries in each mouth of the students of Al-Ihsan Islamic boarding school students. MT value for Al-Ihsan Islamic boarding school students is 0.55 , which means that there is at least 1 tooth lost due to caries in each mouth of Al-Ihsan Islamic Boarding School students, while the FT value for Al-Ihsan Islamic Boarding School students is 0, 06 which means that there are at least 1 tooth patched because of caries in each mouth of the students of Al-Ihsan Islamic boarding school.

The DMF-T index at 266 santri Al-Ihsan Islamic boarding schools was 4,18. According to WHO ( World Health Organization), the index value of Al-Ihsan Islamic boarding school students is moderate (WHO criteria for the DMF-T index 2.74.4 are moderate). This 4.18 number means that on average in each mouth of the students of Al-Ihsan Islamic boarding school there are 4 to 5 teeth that have caries, are lost due to caries and are patched due to caries.

The 2007 National Riskesdas data shows the national DMF-T index of 4.853 . This means that the average tooth decay in the Indonesian population is 5 teeth per person. The biggest component is tooth extraction / MT of 3.86 , it can be said that the average Indonesian population has 4 teeth that have been extracted because of caries (National Riskesdas, 2007). Research data at Al-Ihsan Islamic boarding school shows lower results than Riskesdas data, 4 , 18 which can be concluded that there is a decrease in the results of the Riskesdas report.

Based on table 3 teeth affected by caries (D) a total of 949 cases, while Table 5 shows that there were D1 (teeth that had caries incipient) as many as 280 cases and D2 (teeth that had media caries as many as 335 cases. This means 
that 334 other teeth have experienced media caries or deep caries. The results of the study shown in table 5 show that the average value of D1 in Al-Ihsan Islamic boarding school students is 1.05 , which means that there are 1 to 2 teeth that experience D1 in every student in Al-Ihsan Islamic boarding school. The average value of D2 in AlIhsan Islamic boarding school students is 1.25 , which means there are at least 1 to 2 teeth that have experienced D2 in every Al-Ihsan Islamic boarding school students.

\section{DISCUSSION}

Table 2 shows the prevalence of caries in AlIhsan Islamic boarding school students at $90.6 \%$. This means that $90.6 \%$ of Al-Ihsan Islamic boarding school students have caries. The Household Health Survey in 2004 showed a caries prevalence rate of $90.05 \%$ in the Indonesian population. ${ }^{7,8}$ This shows that the prevalence rate of caries in Al-Ihsan boarding school students is greater than the results of the 2004 Household Health Survey.

Table 3 and Table 4 present the components of the index $\mathrm{D}, \mathrm{M}$, and $\mathrm{F}$ in students in Al-Ihsan Islamic boarding school students. The DMF-T index as an indicator of dental health is a sum of the DT, MT, and FT index which shows how much tooth decay a person has experienced either in the form of Decay (carious or cavities), Missing (teeth extracted due to caries), and Filling (teeth patched or clogged because of caries. ${ }^{4}$

The results shown in Table 4 show that the average value of D-T in Al-Ihsan Islamic boarding school students is 3.56 , which means that there are 3 to 4 teeth that have caries in each mouth of students of Al-Ihsan Islamic boarding school students. MT value for Al-Ihsan Islamic boarding school students is 0.55 , which means that there is at least 1 tooth lost due to caries in each mouth of Al-Ihsan Islamic boarding school students, while the FT value for Al-Ihsan Islamic Boarding School students is 0,06 which means that there are at least 1 tooth patched because of caries in each mouth of the students of Al-Ihsan Islamic boarding school.

The DMF-T index of 266 students at Al-Ihsan Islamic boarding school is 4.18. According to WHO (World Health Organization), the index value of Al-Ihsan Islamic boarding school students is moderate (WHO criteria for the DMF-T index 2.74.4 are moderate). ${ }^{9,10}$ This 4.18 figure means that on average in each mouth of the students of AlIhsan Islamic boarding school students there were 4 to 5 teeth that had caries, lost due to caries and patched because of caries.

The 2007 National Riskesdas data shows the national DMF-T index of 4.85.4 This means that the average tooth decay in the Indonesian population is 5 teeth per person. The biggest component is tooth extraction / M-T of 3.86, it can be said that the average Indonesian population has 4 teeth that have been extracted due to caries. ${ }^{4}$

Research data in Al-Ihsan Islamic boarding school shows lower results than Riskesdas data, which is 4.18 , which can be concluded that there is a decrease from Riskesdas report results. Based on Table 3, 949 cases of caries affected teeth (D), while Table 5 shows that there were 280 cases of dental caries insipien and 280 cases of D2 (teeth that had media caries in 335 cases), which means that 334 teeth others have experienced media caries or deep caries.

The results shown in Table 5 show that the average value of D1 in Al-Ihsan Islamic boarding school students is 1.05 , which means that there are 1 to 2 teeth that experience D1 in every student in Al-Ihsan Islamic boarding school. The average value of D2 in Al-Ihsan Islamic boarding school students is 1.25 , which means there are at least 1 to 2 teeth that have experienced D2 in every Al-Ihsan Islamic boarding school students.

\section{CONCLUSION}

Prevalence of caries and DMF-T index with D1-D2 scale on students are prevalence of dental caries is higher than prevalence in 2004 Household Health Survey. DMF-T index is moderate, while the D1 scale found 280 cases and the D2 scale found 335 cases.

\section{REFERENCES}

1. World Health Organization. Constitution of the World Health Organization - Basic Documents. $45^{\text {th }}$ ed, Supplement. Geneva: World Health Organization; 2006.

2. The Ministry of Health of the Republic of Indonesia. Law of the Republic of Indonesia 
Number 36 of 2009. Jakarta: 2009.

3. Pintauli S, Taizo H. Law of the Republic of Indonesia Number 36 of 2009.Field. Publisher: USU Press. 2008. p.4-9, 15-16

4. The National Institute of Health Research and Development Ministry of Health Republic of Indonesai. Report on Basic Health Research Results (RISKESDAS) West Java Province 2007. Jakarta: Minister of Health of Republic of Indonesia. 2008. p. 95-108

5. Santrock JW. Adolescence perkembangan remaja. $6^{\text {th }}$ ed. Boston. Mc Graw. Erlangga. 2003.

6. Notoatmodjo S, Sarwono S. Pengantar ilmu perilaku kesehatan. Jakarta: Behavioral Sciences;Sociology, Medical. 1985.

7. Statistics Indonesia (BPS). Indonesia -
Household Socio-Economic Survey 2004. Jakarta: Statistics Indonesia; 2004.

8. Rahmawati AD, Nasserie W, Adang RAF. Evaluation of the mummification treatment at Conservative Dentistry Clinics. Padjadjaran J Dent. 2012;24(1):24-8.

9. Anaise JZ. Measurement of dental caries experience--modification of the DMFT index. Community Dent Oral Epidemiol. 1984;12(1):43-6.

10. Moreira D, Spolidório DM, Rodrigues JA, Boriollo MF, Pereira CV, Rosa EA, et al. Candida spp. biotypes in the oral cavity of school children from different socioeconomic categories in Piracicaba-SP, Brazil. Pesqui Odontol Bras. 2001;15(3):187-95. 